\title{
Differential Action of Silver Nanoparticles on ABCB1 (MDR1) and ABCC1 (MRP1) Activity in Mammalian Cell Lines
}

\author{
Damian Krzyzanowski ${ }^{1,2, *}$, Marcin Kruszewski ${ }^{3,4}$ and Agnieszka Grzelak ${ }^{5}$ \\ 1 Department of Pediatrics, Oncology and Hematology, Medical University of Lodz, 91-738 Lodz, Poland \\ 2 Laboratory of Epigenetics, Institute of Medical Biology, Polish Academy of Sciences, 93-232 Lodz, Poland \\ 3 Centre for Radiobiology and Biological Dosimetry, Institute of Nuclear Chemistry and Technology, \\ 03-195 Warsaw, Poland; m.kruszewski@ichtj.waw.pl \\ 4 Department of Molecular Biology and Translational Research, Institute of Rural Health, 20-090 Lublin, Poland \\ 5 Department of Molecular Biophysics, University of Lodz, 90-237 Lodz, Poland; \\ agnieszka.grzelak@biol.uni.lodz.pl \\ * Correspondence: damian.krzyzanowski@umed.lodz.pl
}

Citation: Krzyzanowski, D.;

Kruszewski, M.; Grzelak, A.

Differential Action of Silver

Nanoparticles on ABCB1 (MDR1) and ABCC1 (MRP1) Activity in

Mammalian Cell Lines. Materials 2021, 14, 3383. https://doi.org/10.3390/

ma14123383

Academic Editor: Tania Limongi

Received: 24 May 2021

Accepted: 13 June 2021

Published: 18 June 2021

Publisher's Note: MDPI stays neutral with regard to jurisdictional claims in published maps and institutional affiliations.

Copyright: (c) 2021 by the authors. Licensee MDPI, Basel, Switzerland. This article is an open access article distributed under the terms and conditions of the Creative Commons Attribution (CC BY) license (https:/ / creativecommons.org/licenses/by/ $4.0 /)$.

\begin{abstract}
Silver nanoparticles (AgNPs), due to their unique properties have been receiving immense attention in recent years. In addition to their antibacterial and antifungal activities, AgNPs also cause apoptosis, mitochondria disfunction, nucleic acid damage and show potent anticancer properties in both multidrug resistance (MDR) and sensitive tumors. The MDR phenomenon, caused by the presence of ATP-binding cassette (ABC) proteins, is responsible for the failure of chemotherapy. Thus, investigating the influence of widely used AgNPs on ABC transporters is crucial. In the present study, we have examined the cytotoxicity of silver nanoparticles of a nominal size of $20 \mathrm{~nm}(\mathrm{Ag} 20)$ on the cell lines of different tissue origins. In addition, we have checked the ATP-binding cassette transporters' activity and expression under AgNP exposure. The results indicate that Ag20 shows a toxic effect on tested cells, as well as modulating the expression and transport activity of ABC proteins.
\end{abstract}

Keywords: silver nanoparticles; ABC transporters; ATP-binding cassette; multidrug resistance; P-glycoprotein

\section{Introduction}

Nanotechnology is a relatively new field of science connecting the achievements of biology, chemistry, physics and engineering. Synthetic nanomaterials, defined as any molecules of a diameter smaller than $100 \mathrm{~nm}$, have received tremendous attention and have found widespread applications in life sciences as well as everyday life, due to their unique designs and property combinations, compared with bulk materials. Their small size and developed surface, resulting in a large specific surface to volume ratio, make them highly reactive molecules with unique physical and chemical properties [1,2].

Among the list of thousands of commercially available products, nanomaterials containing silver nanoparticles (AgNPs) are mostly used. Nanosilver has effective antibacterial, antiviral and antifungal properties. However, the mechanism of action of AgNPs is still not well understood. The development of nanotechnology and the extensive use of AgNPs are provoking discussion about the toxicity of these molecules on the environment in the direct way, or through indirect action [3,4]. Considering such a wide spectrum of applications for AgNPs, one must be wary of exposure to them [5]. AgNPs penetrate the human organism through the respiratory and digestive systems, as well as through the skin, both intact and damaged [6]. They also penetrate the blood-brain or blood-testis barriers. Because of their small size, AgNPs can be easily transported through the blood circulation system [7]. The transport of AgNPs inside cells begins with their internalization and translocation into lysosomes. The main mechanisms of AgNPs penetrating into the cell are via clathrin-dependent endocytosis [8], mediated by caveolae (i.e., clathrin-independent 
endocytosis), lipid-dependent endocytosis and, to a lesser extent, micropinocytosis [9], but also through direct diffusion through the cell membrane into the cytoplasm [10-12]. During endocytosis, nanoparticles are trapped in the early endosome formed from the cell membrane, which then transforms into the late endosome and finally the lysosome. The penetration of AgNPs is a process strictly dependent on the incubation time, concentration, size, shape, surface and charge modification [13]. Smaller nanoparticles $(>20 \mathrm{~nm})$ are biologically more effective (they can penetrate the cell nucleus or mitochondria [14]).

When AgNPs are internalized, they induce a number of biological effects, including: intracellular oxidative stress by generation of reactive oxygen species and, in consequence, stimulation of the I $\kappa \mathrm{B}$ kinase/nuclear factor- $\mathrm{kB}$ (IKK/NF- $\mathrm{KB}$ ) and nuclear factor-erythroid 2-related factor 2/Kelch-like ECH-associated protein 1 (Nrf2/KEAP1) pathways [15,16], and cell membrane impairment and damage. As an indirect action, they trigger the programmable cell death-apoptosis, inflammatory processes and disorders of mitochondrial functioning $[17,18]$. They exert a significant inhibitory effect on RNA by suppressing the transcription through RNA polymerase-silver binding [19] and cause DNA damage, genotoxicity, chromosomal aberrations, inhibition of proliferation and many others [1,20-22].

Many studies in the field of AgNP toxicity have been carried out, giving the evidence of the remarkable anticancer features. However, there is little information concerning the effect of these molecules on the $\mathrm{ABC}$ transporters, which are particularly important from a clinical point of view. There are data suggesting that quantum dots are actively co-transported with cholesterol by ABCB1 [23]. On the other hand, nanoparticles have been proposed as vehicles allowing the introduction of bound or encapsulated drugs to circumvent the activity of multidrug transporters. Although there is evidence that AgNPs have a notable antiproliferative effect, induce apoptosis mediated cell death, cause cell cycle arrest, and modulate $\mathrm{ABC}$ transporter activity in both drug sensitive and in the multidrug resistant cancer cells [24], there is a little information on the effect of AgNPs on the MDR protein expression. Thus, further investigation in this area is strongly required.

ATP-binding cassette $(\mathrm{ABC})$ transporters are present in all living organisms, from bacteria to man, and they are among the largest and most widely expressed protein superfamilies known [25]. In humans, $49 \mathrm{ABC}$ genes have been described and organized into seven subfamilies (A-G) named according to the nomenclature based mainly on a sequence homology $[26,27]$. The $A B C$ superfamily consists mainly of membrane proteins that transport various types of substrates, including sugars, amino acids, lipids, sterols, peptides, endogenous metabolites, ions and wide spectrum of xenobiotics [28,29]. A common feature of the above-mentioned proteins is the fact that they are active transporters-they pump substrates against the concentration gradient using the energy from ATP hydrolysis. $\mathrm{ABC}$ transporters are distinguished by highly conservative amino acid sequences (transmembrane domains TMDs) located in the nucleotide-binding domain (NBD), so-called Walker A and Walker B motifs, separated by an "ABC signature" motif responsible for transport [30,31]. The overexpression of $\mathrm{ABC}$ proteins is the main reason for the MDR phenomenon and may potentially be involved in conferring resistance to chemotherapeutic agents as well as leading to anticancer therapy failure.

From a clinical point of view, the key role in the above-mentioned mechanism is played by three ABC proteins: P-glycoprotein (ABCB1/MDR1) [32], multidrug resistance protein 1 (ABCC1/MRP1) [33] and breast cancer resistance protein (ABCG2/BCRP) [34].

The aim of this study was to examine in vitro the effect of AgNPs on the regulation of $\mathrm{ABC}$ transporter expression as well as the activity in the cells of different tissue origins, selected on the basis of in vivo deposition in the animal models $[35,36]$.

\section{Materials and Methods}

2.1. Reagents

The highest-purity reagents available were used to perform all experiments. Dulbecco's Modified Eagle Medium (DMEM), phosphate-buffered saline (PBS), fetal bovine serum (FBS) and trypsin were from Gibco (Thermo Fisher Scientific, Waltham, MA, USA). 
Bare silver nanoparticles of nominal size of $20 \mathrm{~nm}$ (Ag20) were purchased from Plasmachem $\mathrm{GmbH}$ (Berlin, Germany). MycoProbe Mycoplasma Detection Kit were from R\&D Systems (Minneapolis, MN, USA). All other reagents were purchased from Sigma-Aldrich (St. Louis, MO, USA) or Thermo Fisher Scientific (Waltham, MA, USA) unless stated otherwise.

\subsection{Cell Culture}

Non-small cell lung carcinoma: A549 (CCL-185), hepatocellular carcinoma: HepG2 (HB-806), and colorectal adenocarcinoma: SW620 (CCL-22) were purchased from the American Type Culture Collection (ATCC, Manassas, VA, USA) and cultured in $75 \mathrm{~cm}^{2}$ cell culture flasks (Nunc, Roskilde, Denmark) in Dulbecco's Modified Eagle Medium buffered with HEPES to $\mathrm{pH}$ range of 7.1-7.3, supplemented with Glutamax-I and 10\% $(v / v)$ fetal bovine serum (Thermo Fisher Scientific, Waltham, MA, USA) at standard conditions: $37^{\circ} \mathrm{C}$ in a humidified-air atmosphere containing $5 \%$ carbon dioxide. Passages were carried out when the cultures reached $70-85 \%$ confluence. The cells were split with $0.25 \%$ trypsinEDTA, counted by the Countess Automated Cell Counter (Life Technologies, Waltham, MA, USA), and plated at $4 \times 10^{4}$ cells $/ \mathrm{cm}^{2}$ in a new flask or used for experiments. All cells were free of Mycoplasma (tested with MycoProbe Mycoplasma Detection Kit by R\&D, Minneapolis, MN, USA) and were harvested in the exponential growth phase before use.

\subsection{Silver Nanoparticle Preparation}

A stock solution $\left(2 \mathrm{mg} / \mathrm{cm}^{3}\right)$ of bare AgNPs with nominal diameters of $20 \mathrm{~nm}(\mathrm{Ag} 20)$ was prepared freshly before each experiment. Briefly, Ag20 was suspended in $800 \mathrm{~mm}^{3}$ of Mili-Q water, mixed carefully and sonicated with OmniRuptor 4000 with $4.2 \mathrm{~kJ} / \mathrm{cm}^{3}$ total ultrasound energy (Omni International, Kennesaw, GA, USA). Then $100 \mathrm{~mm}^{3}$ of $15 \%$ bovine serum albumin and $100 \mathrm{~mm}^{3}$ of 10-fold concentrated phosphate buffered saline (PBS) were given immediately to aliquots of suspension, mixed well and used to carry out the experiments. The nanoparticles and their behavior in the culture media have been described previously $[37,38]$.

\subsection{Cytotoxicity Assay}

Cytotoxicity of Ag20 was determined using the neutral red assay which is based on the ability of viable cells to incorporate and bind the supravital dye neutral red in the lysosomes (reductants-independent assay). Briefly, $15 \times 10^{3}$ SW620, A549 and HepG2 cells per well in $100 \mathrm{~mm}^{3}$ medium were seeded in 96-well tissue culture plates (Nunc, Roskilde, Denmark) and after at least $24 \mathrm{~h}$ were treated for the appropriate period of 24,48 or $72 \mathrm{~h}$ with Ag20 in the concentration range of $0-300 \mu \mathrm{g} / \mathrm{cm}^{3}$. Then $20 \mathrm{~mm}^{3}$ of $0.33 \%(w / v)$ neutral red solution in PBS was added and incubated for an additional $2 \mathrm{~h}$ at standard conditions. The cells were subsequently washed with PBS and dye was extracted in each well using neutral red fixer: $50 \%(v / v)$ ethanol with $1 \%(v / v)$ acetic acid in Mili-Q water (Merc Millipore (Billerica, MA, USA). Then plates were shaken $10 \mathrm{~min}$ on Thermomixer Comfort (Eppendorf, Hamburg, Germany) and the absorbance was measured using spectrophotometer EnVision Multilabel Reader (Perkin Elmer, Waltham, MA, USA) at $540 \mathrm{~nm}$.

\subsection{RNA Isolation and Real-Time PCR Gene Expression Analysis}

SW620, A549 and HepG2 cells were seeded in 6-well plate (Nunc, Roskilde, Denmark) at density $5 \times 10^{5}$ per well. After $24 \mathrm{~h}$ of culture, cells were treated with $50 \mathrm{\mu g} / \mathrm{cm}^{3}$ Ag20 for 1, 2, 4, $24 \mathrm{~h}$. Subsequently, cells were rinsed with PBS, trypsinized and total RNA was isolated, employing MagNA Pure LC 2.0 Instrument (Roche, Basel, Switzerland) according to the manufacturer's protocol. After genomic DNA removal by RNase free, DNase I digestion, total RNA of $1 \mu \mathrm{g}$ was reverse-transcribed using the SuperScript III First-Strand Synthesis SuperMix (Life Technologies, Waltham, MA, USA). PCR analysis was performed using C1000 Thermal Cycler-CFX384 Real-Time System (Bio-Rad, Hercules, CA, USA) and RealTime ready Human ABC Transporter Panel (Roche, Basel, Switzerland). DNA was omitted in non-template control. The amount of target mRNA in the various 
samples was estimated using the $2^{-\Delta \mathrm{CT}}$ relative quantification method employing Rest2009 v2.0.13 (Qiagen, Hilden, Germany) and presented as heatmaps [39]. Though the same gene panels were used for all cell lines, in some cases expression of a particular gene was under detection limit. In this case the gene is omitted on a heatmap for this cell line.

\subsection{Western Immunoblotting}

The cellular proteins were extracted from SW620, A549 and HepG2 cells with RIPA buffer containing Halt Protease Inhibitor Cocktail (Thermo Fisher Scientific, Waltham, MA, USA), and equal protein amounts (protein concentration of lysates measured by BCA assay, Thermo Fisher Scientific, Waltham, MA, USA) were subjected to SDS-PAGE. After electrophoresis proteins were transferred onto Trans Blot Turbo Mini PVDF membranes with Trans-Blot Turbo Transfer System (Bio-Rad, Hercules, CA, USA), blocked with 5\% BSA and incubated with specific primary antibodies: mouse anti-human ABCB1 (clone F4, Sigma Aldrich, St. Louis, MO, USA). Specific HRP-conjugated secondary antibodies were used (Sigma Aldrich, St. Louis, MO, USA), and protein bands were detected using Pierce ECL Western Blotting Substrate (Thermo Fisher Scientific, Waltham, MA, USA) employing Mini HD (Uvitec, Cambridge, UK). MDR1/ABCB1 Sf9 insect membranes (Solvo Biotechnology, Budaörs, Hungary) were used as a positive control for the presence of $A B C$ proteins, and $\beta$-actin serves as an internal control.

\subsection{Flow Cytometry}

\subsubsection{Calcein Accumulation}

To investigate $A B C B 1$ activity, the calcein assay was performed according to Richter et al. [40] with minor modifications. Calcein acetoxymethyl ester (Cal AM) solution was added to the cells suspension to a final concentration of $200 \mathrm{nM}$ and the kinetic intensity of the median fluorescence was immediately recorded using an LSRII flow cytometer every $2 \mathrm{~min}$ for $12 \mathrm{~min}$ at $37^{\circ} \mathrm{C}$ on the emission channel $530 / 20 \mathrm{~nm}$ to ensure initial conditions. The fluorescence increased with increasing inhibition of $\mathrm{ABCB} 1$-mediated efflux of calcein $\mathrm{AM}$. The ABCB1 activity was determined by calculating the slope of the fluorescence recorded over $12 \mathrm{~min}$, plotted relative to the fluorescence in the presence or absence of $10 \mu \mathrm{M}$ verapamil. The calcein assay was analyzed using the slope of the linear curve determined without inhibitor subtracted from the slope of the linear curve in the presence of the inhibitor. Verapamil-dependent calcein accumulation was calculated.

\subsubsection{BCECF Efflux}

To investigate ABCC1 activity the BCECF efflux assay was performed according to Bachmeie et al. [41] with minor modification. (2',7'-Bis-(2-Carboxyethyl)-5-(and-6)Carboxyfluorescein (BCECF AM) solution was added to the cell suspensions to a final concentration of $1 \mu \mathrm{M}$ and incubated $10 \mathrm{~min}$ at $37^{\circ} \mathrm{C}$. Then the cells were washed with ice cold PBS, resuspended in fresh medium and split into two samples: without inhibitor and with $10 \mu \mathrm{M}$ MK571. The kinetic intensity of the fluorescence median was recorded using an LSRII flow cytometer every $15 \mathrm{~min}$ for $120 \mathrm{~min}$ at $37^{\circ} \mathrm{C}$ on the emission channel $530 / 20 \mathrm{~nm}$. The BCECF assay was analyzed using the area under curve (AUC) of plotting a time-dependent median fluorescence of BCECF curve in the presence or absence of MK571. MK571 dependent BCECF efflux was calculated by subtracting AUC without inhibitor from AUC with inhibitor.

\subsection{Statistical Analysis}

Data are expressed as an arithmetic mean \pm standard deviation (SD), standard error of the mean (SEM) or confidence interval (for curve fitting and $\mathrm{IC}_{50}$ calculations) from at least three independent replicates. In order to show statistically significant differences, the student's $t$-test and one- or two-way ANOVA with Dunnett's or Bonferroni's post hoc test were used. All statistical analyses were performed using GraphPad Prism 7.05 
(Sandiego, CA, USA). The difference between the mean experimental values was considered statistically significant for $p \leq 0.05$.

\section{Results}

In this study we examined the effect of previously defined Ag nanoparticles [37] with a nominal size of $20 \mathrm{~nm}$ on three cell lines of different tissue origin: non-small-cell lung carcinoma (A549), hepatocellular carcinoma (HepG2) and colon carcinoma (SW620).

\subsection{Cell Viability Measurement}

To compare the cytotoxicity effect of Ag20 on A549, HepG2 and SW620, cells were treated with Ag20 with a concentration range from $0-300 \mu \mathrm{g} / \mathrm{cm}^{3}$ and their viability was determined after 24,48 and $72 \mathrm{~h}$ with neutral red assay. The survival curves are shown in Figure 1 , and the $\mathrm{IC}_{50}$ values are presented in Table 1 . The analysis of the $\mathrm{IC}_{50}$ parameter showed that the A549 cell line was the most resistant to the effects of AgNPs, where it was only possible to determine $\mathrm{IC}_{50}$ value after $72 \mathrm{~h}$ of incubation, and was $202.7 \mu \mathrm{g} / \mathrm{cm}^{3}$. The HepG2 cell line was the most sensitive, with the $\mathrm{IC}_{50}$ for 24,48 and $72 \mathrm{~h}$ respectively: 26.1 ; 21.5 and $15.8 \mu \mathrm{g} / \mathrm{cm}^{3}$. As for the SW620 colorectal cancer cell line, the $\mathrm{IC}_{50}$ was for 24,48 and $72 \mathrm{~h}: 59.0 ; 53.8$ and $39.4 \mu \mathrm{g} / \mathrm{cm}^{3}$, respectively.
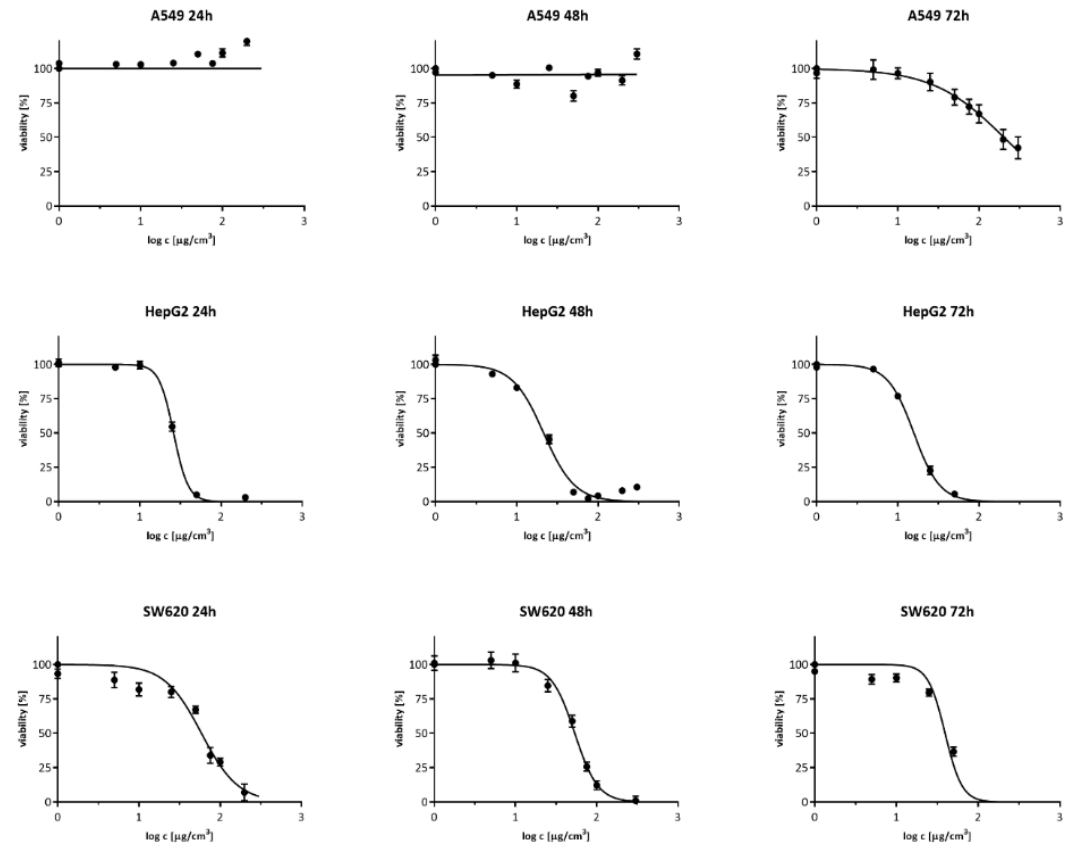

Figure 1. Viability of A549, HepG2 and SW620 as a function of the AgNP concentration; arithmetic mean \pm SEM; $n=3$, neutral red test. Incubation time: 24,48 and $72 \mathrm{~h}$.

Table 1. The summary of Ag20 cytotoxicity in A549, HepG2 and SW620 cell lines. The results are presented as the $\mathrm{IC}_{50}$ mean value $\left(\mu \mathrm{g} / \mathrm{cm}^{3}\right) \pm$ the $95 \%$ confidence interval, $n=3$. " -" was not determined for the $\mathrm{IC}_{50}$ parameter.

\begin{tabular}{cccc}
\hline Time & $\mathbf{2 4} \mathbf{h}$ & $\mathbf{4 8} \mathbf{h}$ & $\mathbf{7 2 ~} \mathbf{h}$ \\
\hline \multirow{2}{*}{ A549 } & - & - & 202.7 \\
& - & - & $(184.9-222.1)$ \\
\hline \multirow{2}{*}{ HepG2 } & 26.1 & 21.5 & 15.8 \\
& $(25.3-27.0)$ & $(20.0-23.1)$ & $(14.9-16.8)$ \\
\hline \multirow{2}{*}{ SW620 } & 59.0 & 53.8 & 39.4 \\
& $(51.9-67.0)$ & $(49.5-58.6)$ & $(34.4-45.1)$ \\
\hline
\end{tabular}




\subsection{Gene Expression Analysis}

After cytotoxicity determination, the effect of $\mathrm{Ag} 20$ on the expression profile of the genes encoding the human ABC transporter superfamily in A549, HepG2 and SW620 cell lines was checked using the qPCR method. Figure 2 shows the expression profile of the $\mathrm{ABC}$ genes presented as heatmaps. The results show that in A549 and HepG2 cells (Figure 2A,B) after short incubation times with $50 \mu \mathrm{g} / \mathrm{cm}^{3}$, AgNPs caused an increase in the expression of $A B C$ transporters except for a few cases, and after $12 \mathrm{~h}$ of incubation, a significant decrease. Interestingly, in the case of SW620 cell line, an opposite trend was observed. (Figure 2C).

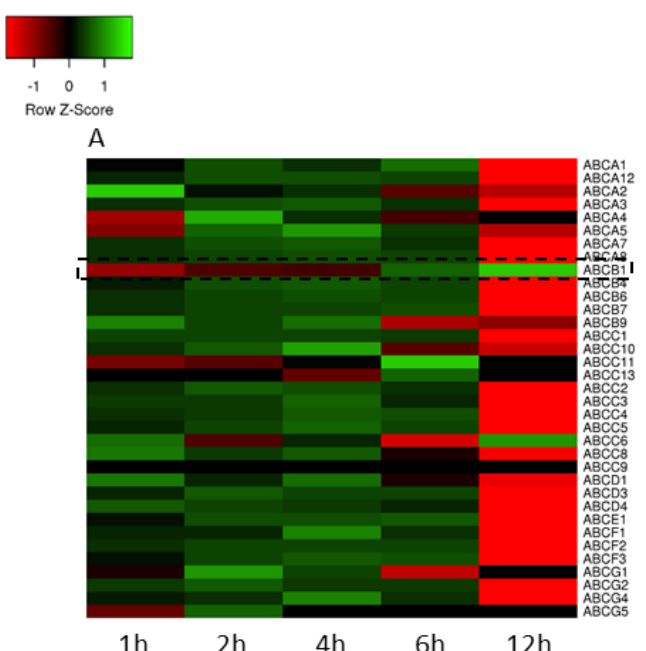

B

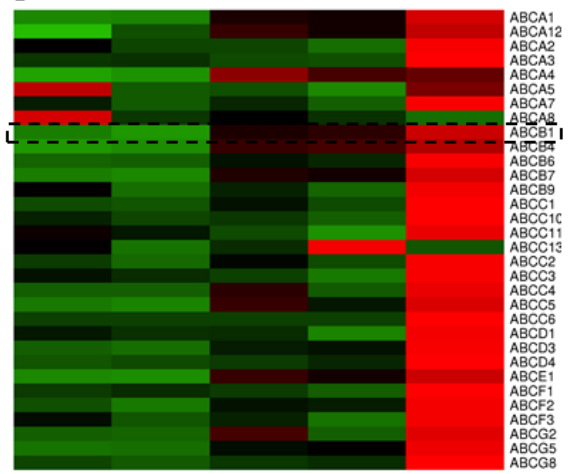

$1 \mathrm{~h} \quad 2 \mathrm{~h} \quad 4 \mathrm{~h} \quad 6 \mathrm{~h} \quad 12 \mathrm{~h}$
C

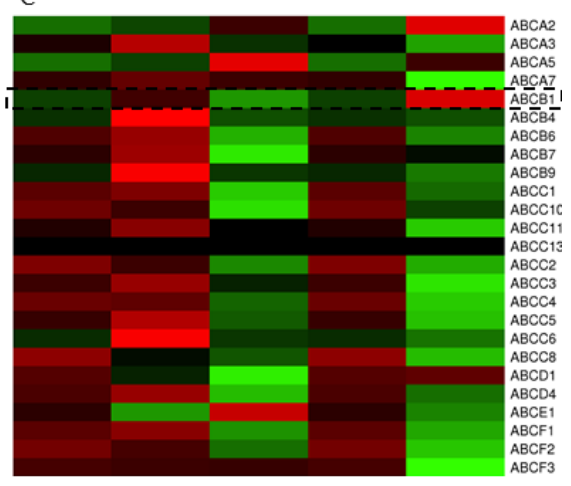

$\begin{array}{lllll}1 \mathrm{~h} & 2 \mathrm{~h} & 4 \mathrm{~h} & 6 \mathrm{~h} & 12 \mathrm{~h}\end{array}$

Figure 2. Heatmaps representing the expression profile of the genes encoding ABC transporters in A549 (A), HepG2 (B) and SW620 (C) cell lines treated for 1, 2, 4, 6 and $12 \mathrm{~h}$ with $50 \mu \mathrm{g} / \mathrm{cm}^{3} \mathrm{Ag} 20$. Rows represent genes and columns represent incubation time. The intensity of each color represents the standardized ratio between each value and the average expression of each gene in all samples. Data expressed as the arithmetic mean of relative gene expression normalized to untreated cells; $n=3$.

\subsection{Transport Activity \\ 3.3.1. Calcein Accumulation}

Extracellularly nonfluorescent, noncharged calcein acetoxymethyl ester penetrates freely inside the cell, where it undergoes hydrolysis, resulting in the formation of a fluorescent calcein. Cal AM is a substrate for ABCB1. The use of a relatively specific ABCB1 inhibitor-verapamil allows the assessment of the activity of the ABCB1 protein by determining the contribution of this protein to Cal AM transport. Examples of the plot of the kinetics of the calcein accumulation are shown in Figure 3A-C. Based on the calcein accumulation plot in A549 cells treated with Ag20, there were no significant differences in the ABCB1 activity compared to control cells within the tested concentrations (Figure 3D). For the HepG2 and SW620 cell lines, a significant decrease in the accumulation of the fluorescent substrate was noted after $2 \mathrm{~h}$ incubation with $50 \mu \mathrm{g} / \mathrm{cm}^{3}$ of AgNPs (Figure 3E,F). 
A

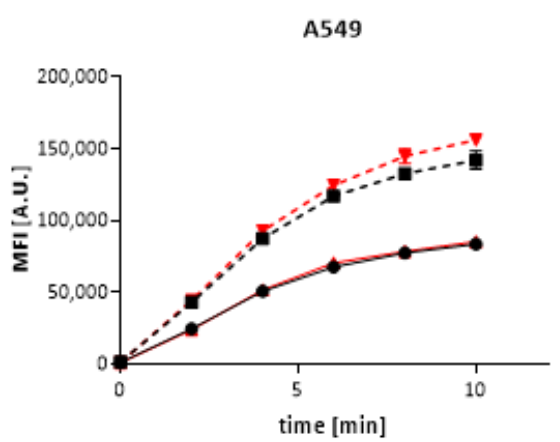

B

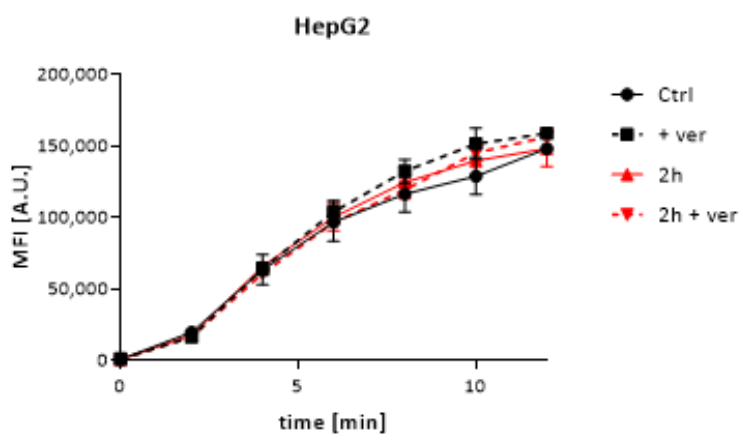

C

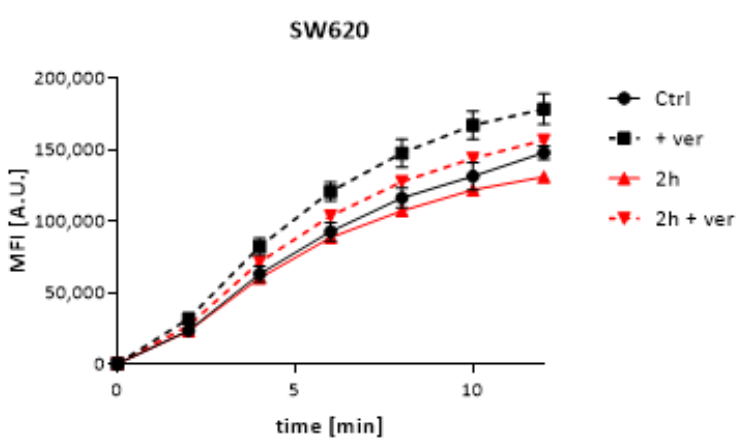

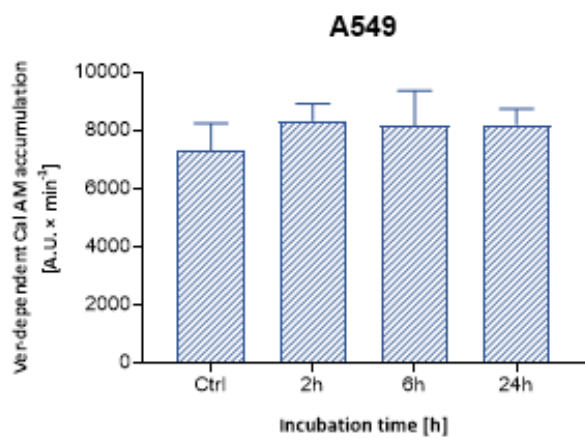

$\mathrm{E}$

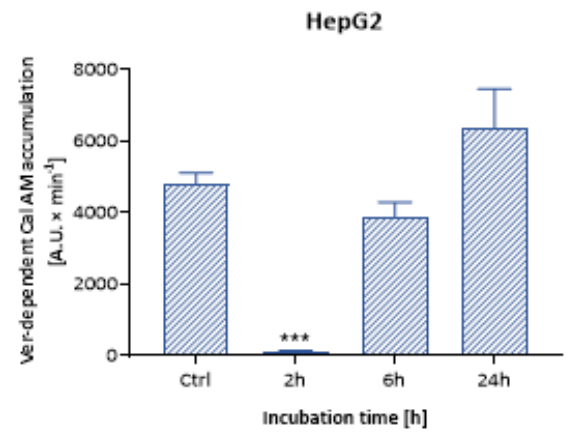

$\mathrm{F}$

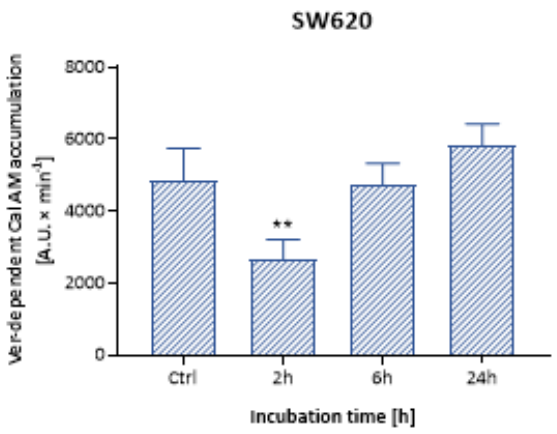

Figure 3. Illustrative plot of intracellular Cal AM accumulation versus time in A549 (A), HepG2 (B) and SW620 (C) cells treated with Ag20 in the presence and absence of verapamil. Verapamil-dependent calcein AM accumulation in A549 (D), HepG2 (E) and SW620 (F) cells treated for 2, 6 and $24 \mathrm{~h}$ with $50 \mu \mathrm{g} / \mathrm{cm}^{3} \mathrm{Ag} 20$ expressed as the slope of the rectilinear segment of the fluorescence increment over time. One-way ANOVA and Dunnett's post hoc test were used. Significance level: ${ }^{* *} p<0.01 ;{ }^{* *} p<0.001$. Data expressed as arithmetic mean $\pm \mathrm{SD} ; n=3$.

\subsubsection{BCECF Efflux}

Likewise calcein AM, BCECF in the form of acetoxymethyl ester penetrates into the cells, where it undergoes hydrolysis to a free fluorescent dye in anionic form. The anion is a substrate of the ABCC1 transporter, thus the ABCC1 activity assay is based on the measurement of the intracellular fluorescence decay. An example of the plot of the BCECF efflux kinetics is shown in Figure 4A-C. The results show that the AgNPs did not have a significant effect on the inhibitor-dependent BCECF efflux in any tested cells, which might prove the lack of influence on the activity of the $\mathrm{ABCC}$ protein (Figure $4 \mathrm{E}, \mathrm{F}$ ). Moreover, for A549 cells, low values of MK571-dependent BCECF efflux may indicate extremely low activity of the above proteins in this line (Figure 4D). 
A

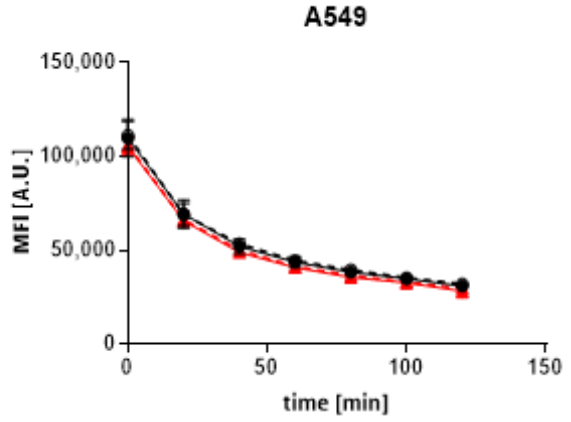

B

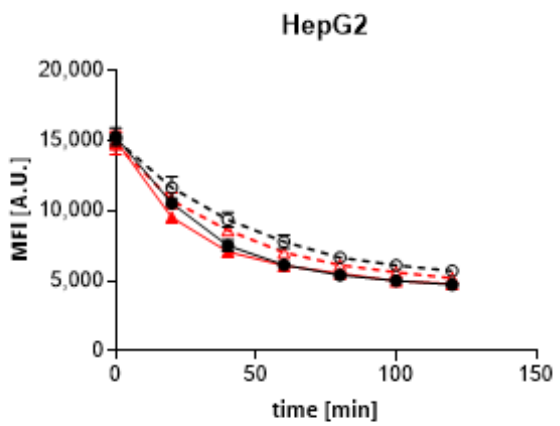

C

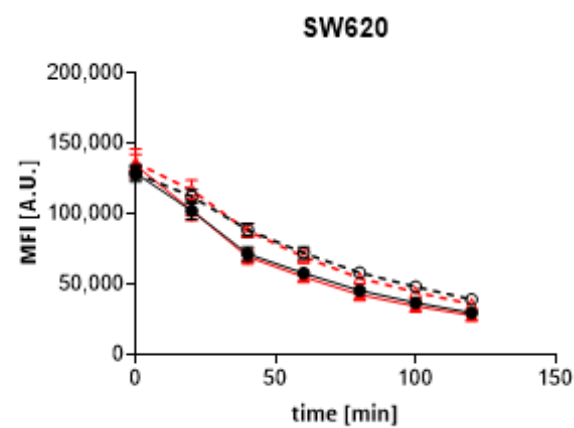

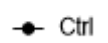

$-\Theta \cdot+$ MK571

$\pm 2 \mathrm{~h}$

$-\mathrm{A} \cdot 2 \mathrm{~h}+\mathrm{MK} 571$

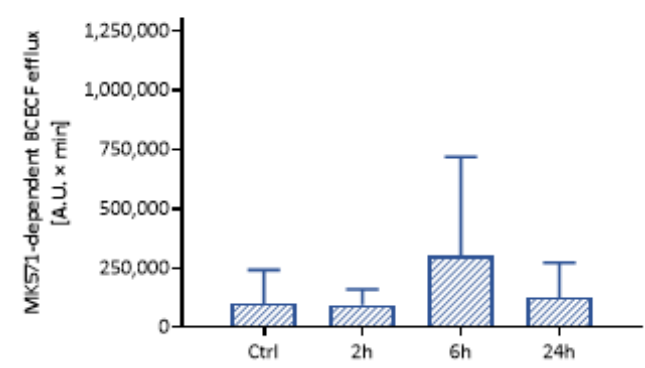

$E$

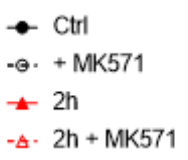

HepG2

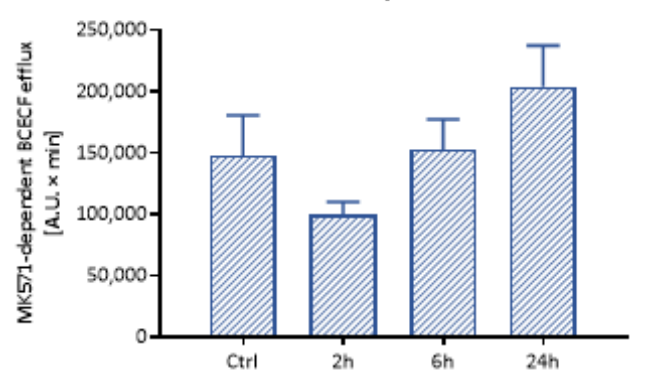

$\mathrm{F}$

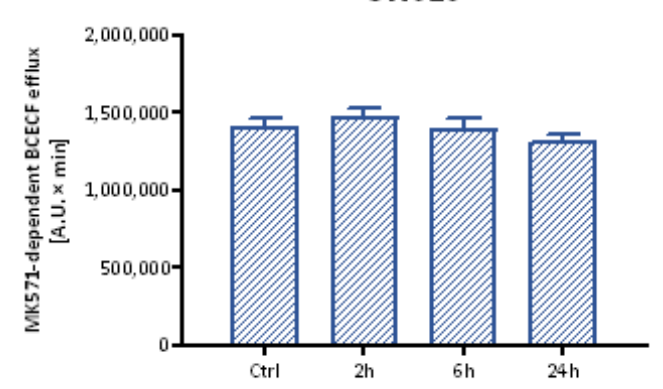

Figure 4. Illustrative plot of intracellular BCECF efflux versus time in A549 (A), HepG2 (B) and SW620 (C) cells treated with Ag20 in the presence and absence of MK571. MK571-dependent BCECF efflux in A549 (D), HepG2 (E) and SW620 (F) cell lines treated for 2, 6 and $24 \mathrm{~h}$ with $50 \mu \mathrm{g} / \mathrm{cm}^{3} \mathrm{Ag} 20$ expressed as the area under the curve of the fluorescence decay over time. One-way ANOVA and Dunnett's post hoc test were used. Data expressed as arithmetic mean \pm SD; $n=3$.

\subsection{Western Immunoblotting}

The densitometric analysis of the expression of ABCB1 in A549, HepG2 and SW620 cells was performed under the influence of 25 and $50 \mu \mathrm{g} / \mathrm{cm}^{3}$ of Ag20 to check if the decrease in P-glycoprotein activity was not associated with decreased protein expression (Table 2). There was a slight decreasing tendency in the expression of protein in A549 and SW620 (Figure 5A,C) cells treated with Ag20 and no differences in HepG2 cells compared to control cells (Figure 5B).

Table 2. Densitometry quantification of ABCB1 protein expression. Data normalized to untreated cells.

\begin{tabular}{|c|c|c|c|c|c|c|}
\hline \multirow{2}{*}{$\begin{array}{l}\text { Dose } \\
\text { Time }\end{array}$} & \multicolumn{3}{|c|}{$25 \mu \mathrm{g} / \mathrm{cm}^{3}$} & \multicolumn{3}{|c|}{$50 \mathrm{\mu g} / \mathrm{cm}^{3}$} \\
\hline & $2 \mathrm{~h}$ & $6 \mathrm{~h}$ & $24 \mathrm{~h}$ & $2 \mathrm{~h}$ & $6 \mathrm{~h}$ & $24 \mathrm{~h}$ \\
\hline A549 & 0.81 & 0.87 & 0.77 & 0.83 & 0.75 & 0.70 \\
\hline HepG2 & 1.02 & 1.03 & 1.15 & 1.06 & 0.91 & 0.90 \\
\hline SW620 & 0.70 & 0.72 & 0.64 & 0.59 & 0.66 & 0.69 \\
\hline
\end{tabular}




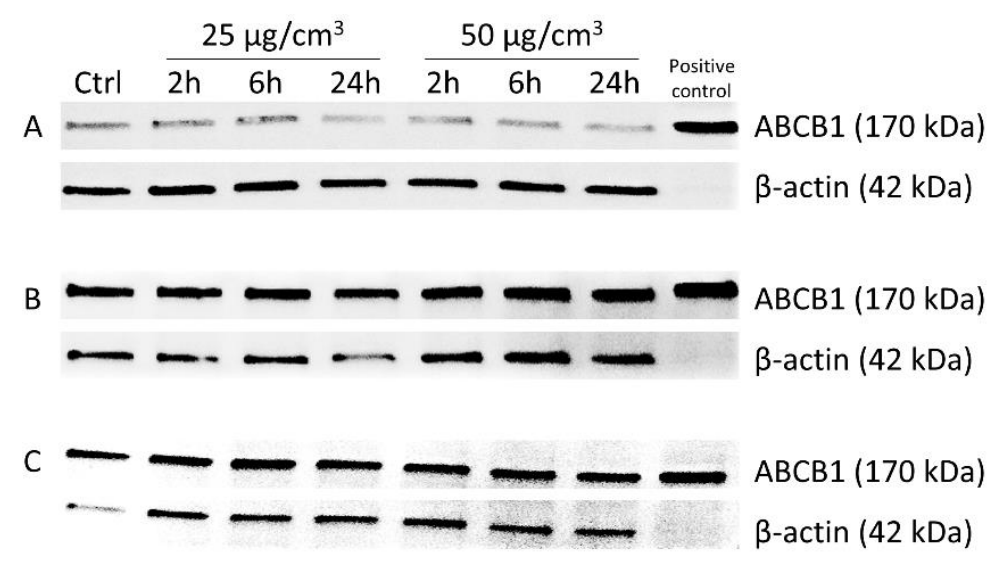

Figure 5. Immunodetection of ABCB1 in A549 (A), HepG2 (B) and SW620 (C) cells treated with 25 and $50 \mu \mathrm{g} / \mathrm{cm}^{3} \mathrm{Ag} 20$ for 2, 6 and $24 \mathrm{~h}$. MDR1/ABCB1 Sf9 insect membrane was used as a positive control for the presence of $\mathrm{ABC}$ protein, and $\beta$-actin serves as an internal control.

\section{Discussion}

Growing interest in nanomaterials and their increasing use make humans vulnerable to exposure to them, and therefore there is an urgent need to address nanoparticle risk assessment. Based on the in vivo studies, it has been shown that AgNPs enter the circulatory system both by inhalation and after ingestion, and then are further deposited in many organs, mainly the lungs, liver, spleen, kidneys, brain, heart, testes and intestines [42,43]. Thus, for experimental purposes, we chose SW620, A549 and HepG2 cell lines corresponding to the colon, lung and liver tissue, respectively.

Analysis of AgNP cytotoxicity showed that all tested cell lines responded in a concentration dependent manner. However, the A549 cell line was the most resistant, whereas the HepG2 cell line was the most sensitive. These results are in line with previous data [44], where the proposed explanation of this phenomenon was the fact that A549 cells are more resistant to stress inducing factors, such as xenobiotics, due to the mutations in the main pathways activated in response to oxidative stress-nuclear factor-erythroid 2-related factor 2/Kelch-like ECH-associated protein 1 (NRF2/KEAP1) [45], nuclear transcription factor $\mathrm{kB}(\mathrm{NF}-\mathrm{kB})$ and $\mathrm{K}-\mathrm{Ras}[46,47]$. This is in line with the general picture of AgNP toxicity. Silver nanoparticles easily penetrate into the cells and release water-soluble toxic ionic silver $\mathrm{Ag}^{+}$within the cytoplasm, which is very reactive [48]. Moreover, AgNPs and released $\mathrm{Ag}^{+}$silver ions strongly react with thiol groups of reduced glutathione and other proteins, such as thioredoxin or thioredoxin peroxidase that may affect their activity and further potentiate oxidative stress and cellular toxicity. Kovács et al. concluded that the reduced viability of Colo205 and Colo320 (P-glycoprotein overexpressing cells) caused by AgNPs exposition was mediated by caspase 3 dependent apoptosis and attenuation of oxidative stress messengers, such as: $p 21$, survivin and sod-1 genes [24].

The main aim of the study was to investigate the effect of AgNPs on the modulation of expression and activity of the MDR proteins in cancer cells of various tissue origin. Since the ability of AgNPs to induce oxidative stress is well documented [49-52], they should have also the potential to regulate many physiological processes, dependent on cellular redox status. Among others, expression of some MDR proteins might be regulated by oxidative stress dependent factors, such as NF- $\mathrm{kB}$ that is one of the key transcription factors activated by reactive oxygen species. NF- $\mathrm{KB}$ might be involved in the regulation of MDR protein expression as a promoter region domain of the MDR1 gene contains NF- $\mathrm{kB}$ binding sites [53]. Indeed, Terada et al. showed that P-glycoprotein expression in Caco-2 cells was increased in response to $1 \mu \mathrm{M}$ of hydrogen peroxide, but decreased upon exposure to the compound at a concentration of $10 \mathrm{mM}$ [54].

In this work, the analysis of $\mathrm{ABC}$ gene expression has also shown that in $\mathrm{A} 549$ and HepG2 cells, a short time of incubation with $50 \mu \mathrm{g} / \mathrm{cm}^{3} \mathrm{Ag} 20$ resulted in an increase of the $A B C$ proteins' $m R N A$ level during the $6 \mathrm{~h}$ after treatment, however a clear decrease 
was observed after $12 \mathrm{~h}$. The opposite situation was noticed in the case of SW620 cells, where an initial decrease (up $2 \mathrm{~h}$ ) in the mRNA level of ABC proteins was accompanied by its gradual increase (Figure 2). The most likely reason for these differences may be the disparate expression levels of $A B C$ transporters in the tested lines. Szakács et al. have profiled mRNA expression of the 48 known human $\mathrm{ABC}$ transporters in 60 diverse cancer cell lines used by the National Cancer Institute to screen for anticancer activity. Results clearly indicate differences in the expression of ABC proteins in A549 and SW620 cell lines [55].

In the further work, we focused on closer characterization of the functional activity of the $\mathrm{ABCC} 1$ and $\mathrm{ABCB} 1$ proteins, which are important from the clinical point of view. Analysis of the functional activity of $A B C C 1$ and $A B C B 1$ proteins revealed a reduced verapamil-dependent calcein accumulation in HepG2 and SW620 cells, reflecting the reduced activity of ABCB1, and no difference in A549 cells (Figure 3). In line with this, the expression of the $\mathrm{ABCB} 1$ protein was decreased for almost all the times and AgNPs concentrations tested (Figure 5). These results are in concordance with literature data. Kovács et al. showed in a colorectal cancer model that biocompatible AgNPs coated with citrate, about $28 \mathrm{~nm}$ in diameter, modulated the expression and activity of P-glycoprotein in Colo320 cells. The authors concluded that the decreased expression of the transporter contributed to the decreased activity of this protein, limiting the efflux of rhodamine 123-an ABCB1 substrate. However, the question still remains whether AgNPs exert a direct inhibitory effect on the $A B C$ transporter or just disrupt mitochondrial function and impaired ATP production, or perhaps through transcriptional silencing of the MDR1 gene [24].

An inhibited efflux of calcein was also observed in the MDCKII-MDR1 cell line treated with $\mathrm{AgNO}_{3}$ and $\mathrm{AgNPs}(23 \mathrm{~nm}$ ). Interestingly, only AgNPs increased the calcein accumulation in wild type MDCKII cell line, that might suggest the direct interaction of NPs with proteins, rather than the indirect action through thiol group inhibition or mitochondrial interactions. The authors confirmed the observed phenomenon in an in vivo model using Daphnia magna, where an increased accumulation of calcein was observed after $60 \mathrm{~min}$ exposure to AgNPs [56]. The inhibition of ABCB1 by citrate-modified AgNP function was also observed in MCF-7 and MCF-7/KCR (cells with ABCB1 overexpression). While the treatment of MCF-7/KCR cells with $5 \mathrm{~nm}$ AgNPs had no effect on the transport activity of the $\mathrm{ABCB} 1$ protein, treatment with a $75 \mathrm{~nm}$ particle accumulation of rhodamine 123 inhibited the P-glycoprotein. Interestingly, the authors did not observe statistically significant changes in the amount of P-glycoprotein in MCF-7/KCR cells after $65 \mathrm{~h}$ incubation with both 5 and $75 \mathrm{~nm}$ AgNPs. They concluded that reduced ABCB1 transporter activity was not coupled to modulated protein expression in MCF-7/KCR cells, but rather to disturbances in mitochondrial activity, misfolding of $\mathrm{ABCB} 1$ protein causing ER stress and mistrafficking [57]. These data are partially in line with our results. We have noticed a similar phenomenon of decreased activity of ABCB1 after $2 \mathrm{~h}$ incubation with Ag20, without affecting protein expression in HepG2 and SW620 cells. Interestingly, no such effect was observed for longer incubation times.

On the contrary, despite the fluctuations of ABCC proteins' mRNA levels, no effect of AgNPs on the functional activity of transporters from the ABCC subfamily was observed on any tested cell lines and incubation times (Figure 2). This suggests different mechanisms of regulation of expression and activity of $\mathrm{ABCC} 1$ and $\mathrm{ABCB} 1$ proteins.

Discordant mRNA levels and ABCB1 protein expression due to AgNP treatment are not fully understood. The regulation of gene product expression involves a series of linked processes that contribute to establishing the rates of protein production and turnover. These include, among others: translation rates (influenced by the mRNA sequence-e.g., upstream open reading frames); translation rate modulation (modulated through the binding of proteins or noncoding RNA to regulatory elements on the transcript); modulation of a protein's lifespan by the complex ubiquitin-proteasome pathway; or protein synthesis 
delay (transcript changes affect protein levels with a particular delay) [58-61]. All these processes might be regulated under oxidative stress [62,63].

Concluding, the obtained results show the complexity of the mechanism of action of AgNPs on transcriptional regulation, post-translational processing and the activity of proteins related to the phenomenon of MDR. It is not known yet whether the AgNPs act directly on the transporter by binding to the protein, thus changing its activity, or indirectly by blocking the ATPase activity or inducing oxidative stress and modulating ABC protein expression. Further research is necessary to elucidate the exact mechanism of AgNP action on $\mathrm{ABC}$ proteins' functionality.

Author Contributions: Conceptualization, D.K., M.K. and A.G.; methodology, D.K. and A.G.; software, D.K.; validation, D.K. and A.G.; formal analysis, D.K.; investigation, D.K.; data curation, D.K.; writing — original draft preparation, D.K.; writing—review and editing, M.K. and A.G.; visualization, D.K.; supervision, A.G.; project administration, D.K. and A.G.; funding acquisition, D.K. All authors have read and agreed to the published version of the manuscript.

Funding: This research was funded by the National Science Centre, Cracow, Poland, grant number 2014/13/N/NZ3/02692.

Institutional Review Board Statement: Not applicable.

Informed Consent Statement: Not applicable.

Data Availability Statement: The data presented in this study are available on request from the corresponding author.

Conflicts of Interest: The authors declare no conflict of interest.

\section{References}

1. Awasthi, K.K.; Awasthi, A.; Kumar, N.; Roy, P.; Awasthi, K.; John, P.J. Silver nanoparticle induced cytotoxicity, oxidative stress, and DNA damage in CHO cells. J. Nanoparticle Res. 2013, 15, 1898. [CrossRef]

2. Kim, S.; Ryu, D.-Y. Silver nanoparticle-induced oxidative stress, genotoxicity and apoptosis in cultured cells and animal tissues. J. Appl. Toxicol. 2013, 33, 78-89. [CrossRef]

3. Manke, A.; Wang, L.; Rojanasakul, Y. Mechanisms of Nanoparticle-Induced Oxidative Stress and Toxicity. BioMed Res. Int. 2013, 2013, 942916. [CrossRef]

4. Wijnhoven, S.W.; Peijnenburg, W.; Herberts, C.A.; Hagens, W.I.; Oomen, A.G.; Heugens, E.H.; Roszek, B.; Bisschops, J.; Gosens, I.; Van De Meent, D.; et al. Nano-silver A review of available data and knowledge gaps in human and environmental risk assessment. Nanotoxicology 2009, 3, 109-138. [CrossRef]

5. Vance, M.; Kuiken, T.; Vejerano, E.P.; McGinnis, S.P.; Hochella, M.F., Jr; Rejeski, D.; Hull, M.S. Nanotechnology in the real world: Redeveloping the nanomaterial consumer products inventory. Beilstein J. Nanotechnol. 2015, 6, 1769-1780. [CrossRef]

6. Larese, F.F.; D'Agostin, F.; Crosera, M.; Adami, G.; Renzi, N.; Bovenzi, M.; Maina, G. Human skin penetration of silver nanoparticles through intact and damaged skin. Toxicology 2009, 255, 33-37. [CrossRef] [PubMed]

7. Singh, N.; Manshian, B.; Jenkins, G.; Griffiths, S.M.; Williams, P.M.; Maffeis, T.G.; Wright, C.; Doak, S.H. NanoGenotoxicology: The DNA damaging potential of engineered nanomaterials. Biomaterials 2009, 30, 3891-3914. [CrossRef] [PubMed]

8. Maurer, L.; Yang, X.; Schindler, A.; Taggart, R.K.; Jiang, C.; Hsu-Kim, H.; Sherwood, D.R.; Meyer, J.N. Intracellular trafficking pathways in silver nanoparticle uptake and toxicity in Caenorhabditis elegans. Nanotoxicology 2016, 10, 831-835. [CrossRef] [PubMed]

9. Zhang, X.-F.; Shen, W.; Gurunathan, S. Silver Nanoparticle-Mediated Cellular Responses in Various Cell Lines: An in Vitro Model. Int. J. Mol. Sci. 2016, 17, 1603. [CrossRef] [PubMed]

10. Mao, B.-H.; Tsai, J.-C.; Chen, C.-W.; Yan, S.-J.; Wang, Y.-J. Mechanisms of silver nanoparticle-induced toxicity and important role of autophagy. Nanotoxicology 2016, 10, 1021-1040. [CrossRef]

11. Zhang, T.; Wang, L.; Chen, Q.; Chen, C. Cytotoxic Potential of Silver Nanoparticles. Yonsei Med. J. 2014, 55, 283-291. [CrossRef]

12. Zielinska, E.; Zauszkiewicz-Pawlak, A.; Wojcik, M.; Inkielewicz-Stepniak, I. Silver nanoparticles of different sizes induce a mixed type of programmed cell death in human pancreatic ductal adenocarcinoma. Oncotarget 2018, 9, 4675-4697. [CrossRef] [PubMed]

13. Luther, E.M.; Koehler, Y.; Diendorf, J.; Epple, M.; Dringen, R. Accumulation of silver nanoparticles by cultured primary brain astrocytes. Nanotechnology 2011, 22, 375101. [CrossRef] [PubMed]

14. Asharani, P.V.; Mun, G.L.K.; Hande, M.P.; Valiyaveettil, S. Cytotoxicity and Genotoxicity of Silver Nanoparticles in Human Cells. ACS Nano 2009, 3, 279-290. [CrossRef]

15. Shi, J.; Sun, X.; Lin, Y.; Zou, X.; Li, Z.; Liao, Y.; Du, M.; Zhang, H. Endothelial cell injury and dysfunction induced by silver nanoparticles through oxidative stress via IKK/NF- $\mathrm{kB}$ pathways. Biomaterials 2014, 35, 6657-6666. [CrossRef] [PubMed] 
16. Nguyen, T.; Nioi, P.; Pickett, C.B. The Nrf2-Antioxidant Response Element Signaling Pathway and Its Activation by Oxidative Stress. J. Biol. Chem. 2009, 284, 13291-13295. [CrossRef]

17. Kim, S.; Choi, J.E.; Choi, J.; Chung, K.-H.; Park, K.; Yi, J.; Ryu, D.-Y. Oxidative stress-dependent toxicity of silver nanoparticles in human hepatoma cells. Toxicol. Vitr. 2009, 23, 1076-1084. [CrossRef]

18. Yang, E.-J.; Kim, S.; Kim, J.S.; Choi, I.-H. Inflammasome formation and IL-1 $\beta$ release by human blood monocytes in response to silver nanoparticles. Biomaterials 2012, 33, 6858-6867. [CrossRef]

19. Wang, Z.; Liu, S.; Ma, J.; Qu, G.; Wang, X.; Yu, S.; He, J.; Liu, J.; Xia, T.; Jiang, G.-B. Silver Nanoparticles Induced RNA Polymerase-Silver Binding and RNA Transcription Inhibition in Erythroid Progenitor Cells. ACS Nano 2013, 7, 4171-4186. [CrossRef]

20. Awasthi, K.K.; Awasthi, A.; Verma, R.; Kumar, N.; Roy, P.; Awasthi, K.; John, P.J. Cytotoxicity, genotoxicity and alteration of cellular antioxidant enzymes in silver nanoparticles exposed CHO cells. RSC Adv. 2015, 5, 34927-34935. [CrossRef]

21. Sahu, S.C.; Zheng, J.; Graham, L.; Chen, L.; Ihrie, J.; Yourick, J.J.; Sprando, R.L. Comparative cytotoxicity of nanosilver in human liver HepG2 and colon Caco2 cells in culture. J. Appl. Toxicol. 2014, 34, 1155-1166. [CrossRef]

22. Arora, S.; Jain, J.; Rajwade, J.; Paknikar, K. Cellular responses induced by silver nanoparticles: In vitro studies. Toxicol. Lett. 2008, 179, 93-100. [CrossRef] [PubMed]

23. Al-Hajaj, N.A.; Moquin, A.; Neibert, K.D.; Soliman, G.M.; Winnik, F.M.; Maysinger, D. Short Ligands Affect Modes of QD Uptake and Elimination in Human Cells. ACS Nano 2011, 5, 4909-4918. [CrossRef]

24. Kovacs, D.; Szőke, K.; Igaz, N.; Spengler, G.; Molnár, J.; Tóth, T.; Madarász, D.; Rázga, Z.; Kónya, Z.; Boros, I.M.; et al. Silver nanoparticles modulate $\mathrm{ABC}$ transporter activity and enhance chemotherapy in multidrug resistant cancer. Nanomed. Nanotechnol. Biol. Med. 2016, 12, 601-610. [CrossRef] [PubMed]

25. Dassa, E.; Bouige, P. The ABC of ABCs: A phylogenetic and functional classification of ABC systems in living organisms. Res. Microbiology 2001, 152, 211-229. [CrossRef]

26. Dean, M.; Allikmets, R. Complete Characterization of the Human ABC Gene Family. J. Bioenerg. Biomembr. 2001, 33, 475-479. [CrossRef]

27. Dean, M.; Deutsch, S.; Iseli, C.; Bucher, P.; Antonarakis, S.E.; Scott, H.S. The Human ATP-Binding Cassette (ABC) Transporter Superfamily. Genome Res. 2001, 11, 1156-1166. [CrossRef]

28. Schinkel, A.H.; Jonker, J. Mammalian drug efflux transporters of the ATP binding cassette (ABC) family: An overview. Adv. Drug Deliv. Rev. 2012, 64, 138-153. [CrossRef]

29. Glavinas, H.; Krajcsi, P.; Cserepes, J.; Sarkadi, B. The Role of ABC Transporters in Drug Resistance, Metabolism and Toxicity. Curr Drug Deliv. 2004, 1, 27-42. [CrossRef]

30. Gottesman, M.M.; Fojo, T.; Bates, S.E. Multidrug resistance in cancer: Role of ATP-dependent transporters. Nat. Rev. Cancer 2002, 2, 48-58. [CrossRef]

31. Sharom, F.J. ABC multidrug transporters: Structure, function and role in chemoresistance. Pharmacogenomics 2008, 9, 105-127. [CrossRef]

32. Di Pietro, A.; Dayan, G.; Conseil, G.; Steinfels, E.; Krell, T.; Trompier, D.; Baubichon-Cortay, H.; Jault, J.-M. P-glycoproteinmediated resistance to chemotherapy in cancer cells: Using recombinant cytosolic domains to establish structure-function relationships. Braz. J. Med Biol. Res. 1999, 32, 925-939. [CrossRef] [PubMed]

33. Deeley, R.G.; Westlake, C.; Cole, S.P.C. Transmembrane Transport of Endo- and Xenobiotics by Mammalian ATP-Binding Cassette Multidrug Resistance Proteins. Physiol. Rev. 2006, 86, 849-899. [CrossRef] [PubMed]

34. Taylor, N.M.I.; Manolaridis, I.; Jackson, S.M.; Kowal, J.; Stahlberg, H.; Locher, K.P. Structure of the human multidrug transporter ABCG2. Nat. Cell Biol. 2017, 546, 504-509. [CrossRef] [PubMed]

35. Wiemann, M.; Vennemann, A.; Blaske, F.; Sperling, M.; Karst, U. Silver Nanoparticles in the Lung: Toxic Effects and Focal Accumulation of Silver in Remote Organs. Nanomaterials 2017, 7, 441. [CrossRef] [PubMed]

36. Yang, L.; Kuang, H.; Zhang, W.; Aguilar, Z.P.; Wei, H.; Xu, H. Comparisons of the biodistribution and toxicological examinations after repeated intravenous administration of silver and gold nanoparticles in mice. Sci. Rep. 2017, 7, 3303. [CrossRef] [PubMed]

37. Lankoff, A.; Sandberg, W.J.; Wegierek-Ciuk, A.; Lisowska, H.; Refsnes, M.; Sartowska, B.; Schwarze, P.E.; Meczynska-Wielgosz, S.; Wojewodzka, M.; Kruszewski, M. The effect of agglomeration state of silver and titanium dioxide nanoparticles on cellular response of HepG2, A549 and THP-1 cells. Toxicol. Lett. 2012, 208, 197-213. [CrossRef]

38. Kruszewski, M.; Grądzka, I.; Bartłomiejczyk, T.; Chwastowska, J.; Sommer, S.; Grzelak, A.; Zuberek, M.; Lankoff, A.; Dusinska, M.; Wojewódzka, M. Oxidative DNA damage corresponds to the long term survival of human cells treated with silver nanoparticles. Toxicol. Lett. 2013, 219, 151-159. [CrossRef]

39. Babicki, S.; Arndt, D.; Marcu, A.; Liang, Y.; Grant, J.R.; Maciejewski, A.; Wishart, D.S. Heatmapper: Web-enabled heat mapping for all. Nucleic Acids Res. 2016, 44, W147-W153. [CrossRef]

40. Von Richter, O.; Glavinas, H.; Krajcsi, P.; Liehner, S.; Siewert, B.; Zech, K. A novel screening strategy to identify ABCB1 substrates and inhibitors. Naunyn Schmiedeberg's Arch. Pharmacol. 2009, 379, 11-26. [CrossRef]

41. Bachmeier, C.J.; Trickler, W.J.; Miller, D.W. Drug Efflux Transport Properties of 2',7'-Bis(2-carboxyethyl)-5(6)-carboxyfluorescein Acetoxymethyl Ester (BCECF-AM) and Its Fluorescent Free Acid, BCECF. J. Pharm. Sci. 2004, 93, 932-942. [CrossRef] [PubMed]

42. Lee, J.J.; Kim, Y.S.; Song, K.S.; Ryu, H.R.; Sung, J.H.; Park, J.D.; Park, H.M.; Song, N.W.; Shin, B.S.; Marshak, D.; et al. Biopersistence of silver nanoparticles in tissues from Sprague-Dawley rats. Part. Fibre Toxicol. 2013, 10, 36. [CrossRef] 
43. Van Der Zande, M.; Vandebriel, R.J.; Van Doren, E.; Kramer, E.; Rivera, Z.H.; Serrano-Rojero, C.S.; Gremmer, E.R.; Mast, J.; Peters, R.J.B.; Hollman, P.C.H.; et al. Distribution, Elimination, and Toxicity of Silver Nanoparticles and Silver Ions in Rats after 28-Day Oral Exposure. ACS Nano 2012, 6, 7427-7442. [CrossRef]

44. Brzóska, K.; Męczyńska-Wielgosz, S.; Stępkowski, T.M.; Kruszewski, M. Adaptation of HepG2 cells to silver nanoparticlesinduced stress is based on the pro-proliferative and anti-apoptotic changes in gene expression. Mutagenesis 2015, 30, 431-439. [CrossRef] [PubMed]

45. Hayes, J.D.; McMahon, M. NRF2 and KEAP1 mutations: Permanent activation of an adaptive response in cancer. Trends Biochem. Sci. 2009, 34, 176-188. [CrossRef] [PubMed]

46. Stepkowski, T.M.; Kruszewski, M.K. Molecular cross-talk between the NRF2/KEAP1 signaling pathway, autophagy, and apoptosis. Free. Radic. Biol. Med. 2011, 50, 1186-1195. [CrossRef]

47. Valenzuela, D.M.; Groffen, J. Four human carcinoma cell lines with novel mutations in position 12 of c-K-ras oncogene. Nucleic Acids Res. 1986, 14, 843-851. [CrossRef]

48. Hamad, A.; Khashan, K.S.; Hadi, A. Silver Nanoparticles and Silver Ions as Potential Antibacterial Agents. J. Inorg. Organomet. Polym. Mater. 2020, 30, 4811-4828. [CrossRef]

49. Park, M.V.; Neigh, A.M.; Vermeulen, J.P.; De La Fonteyne, L.J.; Verharen, H.W.; Briedé, J.; Van Loveren, H.; De Jong, W.H. The effect of particle size on the cytotoxicity, inflammation, developmental toxicity and genotoxicity of silver nanoparticles. Biomaterials 2011, 32, 9810-9817. [CrossRef]

50. Avalos, A.; Haza, A.I.; Mateo, D.; Morales, P. Cytotoxicity and ROS production of manufactured silver nanoparticles of different sizes in hepatoma and leukemia cells. J. Appl. Toxicol. 2013, 34, 413-423. [CrossRef]

51. Liu, W.; Wu, Y.; Wang, C.; Li, H.C.; Wang, T.; Liao, C.Y.; Cui, L.; Zhou, Q.F.; Yan, B.; Jiang, G.B. Impact of silver nanoparticles on human cells: Effect of particle size. Nanotoxicology 2010, 4, 319-330. [CrossRef]

52. Al Omar, S.Y.; Ali, D.; Alarifi, S.; Harrath, A.H.; Mansour, L.; Alwasel, S.H. Evaluation of cytotoxic, oxidative stress, proinflammatory and genotoxic effect of silver nanoparticles in human lung epithelial cells. Environ. Toxicol. 2013, 30, 149-160. [CrossRef]

53. Feng, Q.; Yang, W.; Gao, Z.; Ruan, X.; Zhang, Y. Up-regulation of P-gp via NF-кB activation confers protection against oxidative damage in the retinal pigment epithelium cells. Exp. Eye Res. 2019, 181, 367-373. [CrossRef] [PubMed]

54. Terada, Y.; Ogura, J.; Tsujimoto, T.; Kuwayama, K.; Koizumi, T.; Sasaki, S.; Maruyama, H.; Kobayashi, M.; Yamaguchi, H.; Iseki, K. Intestinal P-glycoprotein expression is multimodally regulated by intestinal ischemia-reperfusion. J. Pharm. Pharm. Sci. 2014, 17, 266-276. [CrossRef]

55. Szakács, G.; Annereau, J.-P.; Lababidi, S.; Shankavaram, U.; Arciello, A.; Bussey, K.; Reinhold, W.; Guo, Y.; Kruh, G.D.; Reimers, M.; et al. Predicting drug sensitivity and resistance. Cancer Cell 2004, 6, 129-137. [CrossRef]

56. Georgantzopoulou, A.; Cambier, S.; Serchi, T.; Kruszewski, M.; Balachandran, Y.L.; Grysan, P.; Audinot, J.-N.; Ziebel, J.; Guignard, C.; Gutleb, A.C.; et al. Inhibition of multixenobiotic resistance transporters (MXR) by silver nanoparticles and ions in vitro and in Daphnia magna. Sci. Total. Environ. 2016, 569-570, 681-689. [CrossRef] [PubMed]

57. Gopisetty, M.K.; Kovacs, D.; Igaz, N.; Rónavári, A.; Bélteky, P.; Rázga, Z.; Venglovecz, V.; Csoboz, B.; Boros, I.M.; Kónya, Z.; et al. Endoplasmic reticulum stress: Major player in size-dependent inhibition of P-glycoprotein by silver nanoparticles in multidrugresistant breast cancer cells. J. Nanobiotechnol. 2019, 17, 9. [CrossRef] [PubMed]

58. Maier, T.; Güell, M.; Serrano, L. Correlation of mRNA and protein in complex biological samples. FEBS Lett. 2009, 583, 3966-3973. [CrossRef] [PubMed]

59. Cheng, Z.; Teo, G.; Krueger, S.; Rock, T.M.; Koh, H.W.; Choi, H.; Vogel, C. Differential dynamics of the mammalian mRNA and protein expression response to misfolding stress. Mol. Syst. Biol. 2016, 12, 855. [CrossRef]

60. Vogel, C.; Marcotte, E.M. Insights into the regulation of protein abundance from proteomic and transcriptomic analyses. Nat. Rev. Genet. 2012, 13, 227-232. [CrossRef]

61. Liu, Y.; Beyer, A.; Aebersold, R. On the Dependency of Cellular Protein Levels on mRNA Abundance. Cell 2016, 165, 535-550. [CrossRef] [PubMed]

62. Abdelmohsen, K.; Kuwano, Y.; Kim, H.H.; Gorospe, M. Posttranscriptional gene regulation by RNA-binding proteins during oxidative stress: Implications for cellular senescence. Biol. Chem. 2008, 389, 243-255. [CrossRef] [PubMed]

63. Vogel, C.; Silva, G.M.; Marcotte, E.M. Protein Expression Regulation under Oxidative Stress. Mol. Cell. Proteom. 2011, 10. [CrossRef] [PubMed] 